\title{
Analysis of Organizational Culture at PT. Bank Sumut Conventional Sub-Branch Office Medan
}

Dina Annisa Rambe ${ }^{1}$, Harmein Nasution ${ }^{2}$, Linda Trimurni Maas ${ }^{3}$

1,2,3 Universitas Sumatera Utara, Medan, Indonesia

Corresponding Author:@ Dinaannisar6@gmail.com

\begin{tabular}{l} 
ABSTRACT \\
motivation that can unite various views on behavior in order to form a \\
strong organizational culture. One way to measure the effectiveness of a \\
company's organizational culture is to use the Organizational Culture \\
Assessment Instrument (OCAI). This study aims to analyze the dominant \\
type of organizational culture and to evaluate the type of organizational \\
culture expected by the employees of PT Bank Sumut Conventional Sub- \\
Branch Office Medan. Sampling in this study using the Nonprobability \\
sampling method with the Accidental Sampling technique, the number \\
of samples that will be used as respondents in this study is 144 people. \\
The results of this study show that the current dominant cultural profile \\
is a culture that focuses on emphasizing innovation, creativity, and the \\
discovery of something new, namely the Adhocracy culture and for the \\
cultural profile that is expected to be dominant in the future is a culture \\
that focuses on human resource development, loyalty and function of the \\
company as a family, namely the Clan culture. This cultural profile \\
picture can be used as a company for policy making in accordance with \\
the vision, mission, and goals of PT Bank Sumut Conventional Sub- \\
Branch Office Medan Region \\
$\begin{array}{l}\text { Organizational Culture, Cultural Profile, Assessment Instrument } \\
\text { (OCAI) }\end{array}$ \\
\hline
\end{tabular}

\section{INTRODUCTION}

The era of globalization has resulted in increasingly fierce competition between companies in Indonesia. The increasing competition today requires every company to be able to adapt to changes in today's business environment. The competition is extraordinarily tight, companies emerge from various regions with very diverse advantages, aiming to seize the market and defend it. Management is required to be reliable in managing the company, not only to keep the company stable, but also to be able to make "maneuvers" in the midst of this highly developed globalization era. Threats and opportunities that exist must be used as strength to face this dynamic environment. Wibowo (2010) says that cultural change is not easy, because it involves humans who previously had their own culture which was considered good and right. It is very interesting to observe that organizational change is closely related to the culture that is adopted, owned and becomes the character of the organization where 
people gather to work together in utilizing all available resources to achieve goals. When talking about a group of people, it cannot be separated from the values that these actors bring to an organization. Within the organization, values are a source of strength, energy and motivation that can unite various views in behavior in order to form a strong organizational culture.

Saputra and Djastuti (2015) say organizational culture is a collection of beliefs, expectations, and values shared by members of the organization and passed down from one generation to the next. Organizational culture has a role to change the attitudes and behavior of existing human resources or employees in order to increase work productivity to face various challenges in the future. Moeheriono (2012) said that organizational culture is a pattern of organizational beliefs and values that are understood, inspired, and practiced by the organization so that the pattern gives its own meaning and becomes the basis for the rules of behavior in the organization.

Organizational culture influences how leaders and workers assess their working conditions and environment in their company. In addition to assessing internal business conditions, organizational culture affects performance. In another sense, organizational culture affects employee performance directly, organizational culture is also able to influence employee culture, as well as employee culture affects organizational culture as stated by George \& Jones (2012). Changes in environmental demands in the current era of globalization are also felt in the regional development bank in North Sumatra, namely PT Bank Sumut. PT Bank Sumut which is a source of business engaged in the banking sector. The role of PT Bank Sumut is very important in the effort to encourage the economic growth of North Sumatra to be more advanced through the regulation of financial circulation. In 2019 Bank Sumut won the Best Regional Development Bank (BPD) Performance award for 1st place for the asset category of Rp. 25 to Rp. 50 trillion. The award given by The Asian Post was obtained based on the results of research conducted by the Infobank Research Bureau on the performance of financial BUMDs. However, with the changes that are happening at this time, PT Bank Sumut must be ready to maintain its existence in several awards and predicates. PT Bank Sumut must adapt to situations that often change. So that it can determine what steps and strategies must be taken by the organization and its employees to face future demands with changes in organizational culture to encourage the achievement of the company's goals, vision and mission.

Organizational Culture Assessment Instrument (OCAI) is an instrument that measures organizational culture developed by Cameron \& Quinn. OCAI is an instrument in describing the profile of organizational culture (PBO). This 
instrument is a framework developed initially from research conducted on the main indicators of effective organizations. This instrument uses the Competing Value Framework that emerged based on research that focuses on the most important indicators affecting company efficiency. Cameron \& Quinn developed a Competing Value Competing Value Framework (CVF) consisting of two dimensions. The first dimension is based on a structure that distinguishes between flexibility, namely effective criteria that emphasize flexibility, discretion, and dynamics, and controlling, namely effective criteria that emphasize stability, order, and control. While the second dimension is based on effective criteria which emphasizes orientation to the company's internal environment such as integration, and unity with orientation to the company's external environment such as uniqueness, innovation, and competition.

These two dimensions form four quadrants, each of which represents a different indicator of organizational effectiveness. These four quadrants define the core values that form the basis for evaluating the organization and form the type of culture in OCAI, where each group represents opposing or competing assumptions. Each quadrant represents the basic assumptions, orientations, and values - the same elements that make up an organization's culture. The four quadrants are hierarchy, market, clan, and adrochacy (Cameron \& Quinn, 2011).

Rakhman (2018) OCAI has several benefits, including providing an understanding of what is considered important by workers in the organization, as an identification measurement tool prior to changes in the organization, helping to improve the organization's internal communication, so this instrument is very useful in reflecting the direction of an organization based on its culture to support the mission and vision of the organization and also to identify elements within the culture that may conflict with the mission and goals. The purpose of this study was to analyze the dominant type of organizational culture at PT Bank Sumut Conventional Sub-Branch Office Medan, to evaluate the ideal type of organizational culture expected by employees of PT Bank Sumut Conventional Sub-Branch Office Medan in the future.

\section{RESEARCH METHODS}

This research was conducted at all Conventional Sub-Branch Offices of PT Bank Sumut in the Medan area. This research began in August 2021. This type of research uses a descriptive method designed to solve the research problem proposed. The independent variable in this study is organizational culture. The 
type of data in this study used primary data and secondary data. In this study, the data sources were obtained from respondents directly through interviews and questionnaires. The population in this study were all permanent employees at the Conventional Sub-Branch Office of PT Bank Sumut Medan Region which consisted of $25 \mathrm{KCP}$ with a total of 225 people. Sampling method using nonprobability sampling method with Accidental Sampling technique, the number of samples that will be used as respondents in this study are 144 respondents, the number of samples is obtained using the Slovin formula. In processing and analyzing the research data, the Organizational Calure Assessment Instrument (OCAI) is used, which is one of the instruments used to identify the culture in an organization.

\section{RESULTS AND DISCUSSION}

Mapping the Organizational Culture Assessment Instrument (OCAI) of the Company's Overall Organizational Culture.

Mapping of the Organizational Culture Assessment Instrument (OCAI) as a whole was carried out to determine the current trend in the type of culture of PT Bank Sumut Medan Conventional Sub-Branch Office and the expected culture based on the dimensions of dominant characteristics, organizational leadership, employee management, organizational adhesive, strategic emphasis and success criteria. The results of mapping the organizational culture of PT Bank Sumut Conventional Sub-Branch Office Medan Region using the Organizational Culture Assessment Instrument (OCAI) overall organizational culture can be seen as follows:

Table 1. Organizational Culture of PT Bank Sumut Conventional Sub Branch Office Medan Region

\begin{tabular}{|c|l|c|c|}
\hline No & OCAI Mapping & At the moment (\%) & Expected (\%) \\
\hline 1 & Clan & 23 & 27 \\
\hline 2 & Adhocracy & 27 & 25 \\
\hline 3 & Market & 24 & 26 \\
\hline 4 & Hierarchy & 26 & 23 \\
\hline & Total & 100 & 100 \\
\hline
\end{tabular}

Based on Table 1, it can be seen that the current clan culture is $23 \%$ and the expected $27 \%$, meaning that on all dimensions, employees expect the clan culture in the future organizational culture to be further improved by $4 \%$. The current adhocracy culture is $27 \%$ and the expected $25 \%$ means that in all 
dimensions, employees do not expect an adhocracy culture in the organizational culture in the future because there is a $2 \%$ decrease. The current market culture is $24 \%$ and the expected $26 \%$ means that in all dimensions, employees expect the market culture in the future organizational culture to be increased by $2 \%$. Then the current hierarchy culture is $26 \%$ and the expected $23 \%$ means that in all dimensions, employees do not expect a hierarchy culture in the organizational culture in the future because there is a decrease of $3 \%$.

In the overall dimensions of organizational culture based on the dimensions of dominant characteristics, organizational leadership, employee management, organizational adhesive, strategic emphasis and success criteria, the dominant organizational culture currently is adhocracy culture with a percentage of $27 \%$ and the expected culture is clan culture with a percentage of 27\%. Through Table 4.8, a mapping chart of the Organizational Culture Assessment Instrument (OCAI) can be made as follows:

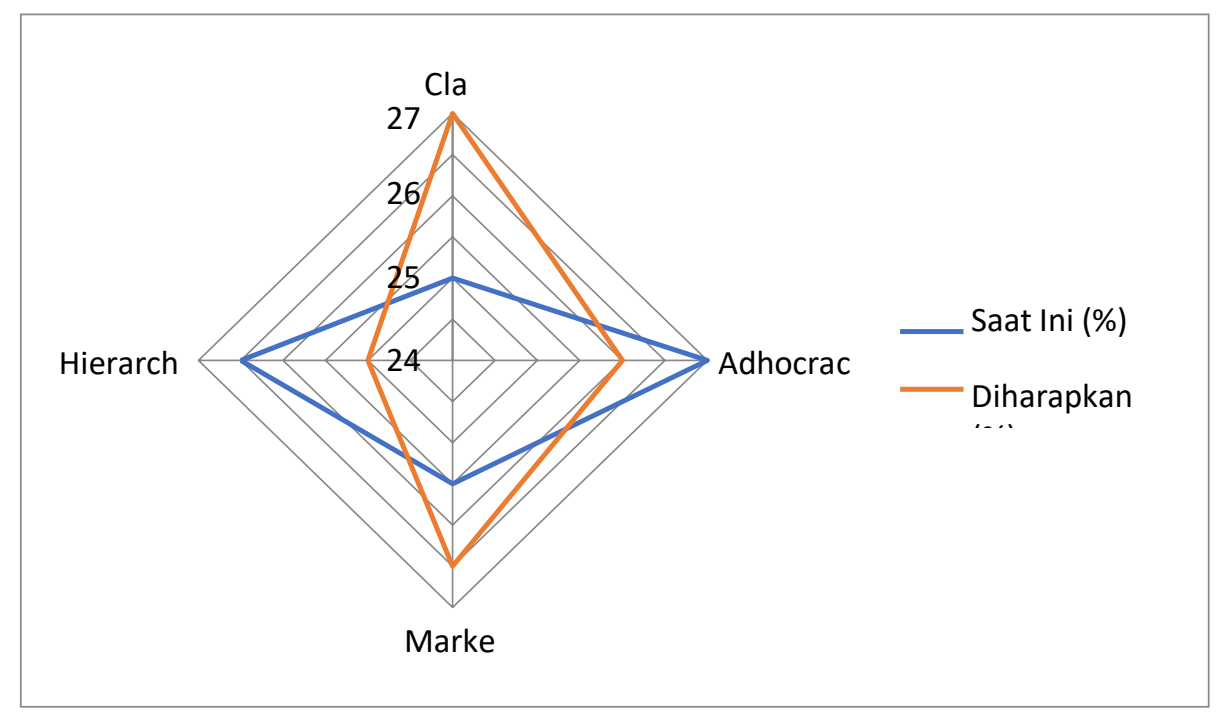

Figure 1. Overall Organizational Culture Mapping Results.

From Figure 1, it can be seen that based on the perceptions of all employees, the current corporate culture is more dominant to the adhocracy culture with a percentage of $27 \%$, while the culture expected by employees is more dominant to the clan culture with a percentage of $27 \%$. Based on the overall dimensions of the current culture perceived by the employees of PT Bank Sumut Conventional Sub-Branch Office Medan Region, they feel that the current organizational culture is an adhocracy culture and the desired culture is a clan culture. This shows that currently employees feel PT Bank Sumut Conventional Sub-Branch Office Medan Region as an organizational culture that emphasizes innovation, creativity, and the discovery of something new and is a dynamic culture or adhocracy culture. The culture that is formed now will certainly make the implementation of corporate values more successful. 
However, it seems that the adhocracy culture is no longer the culture that most employees expect in the future.

The culture that is expected to occur at PT Bank Sumut Conventional SubBranch Office Medan is the clan culture. This shows that employees in the future want to form a strong company accompanied by encouragement for employee moral development and strong teamwork. In the clan culture, the organization is expected to be a fun place like in one big family. Leadership is a mentor who provides facilities and guidance. They prefer the company as a big family rather than an economic entity.

Deal and Kennedy (in Wibowo, 2010) explain that there are situations where top management must consider whether there is a need to internalize or even reshape its culture, namely when the industry is very competitive and the environment is changing rapidly. Meanwhile, Wibowo (2010) reveals that cultural change is needed if sales are flat and the environment is very competitive. Of course the re-establishment of culture does not mean a change in the vision, mission, or values of PT Bank Sumut Conventional Sub-Branch Office Medan, considering the vision that has been set is in accordance with the nature and basic assumptions of the company. However, due to the decline in employee performance appraisals every year, of course it is necessary to have an active implementation of a culture that focuses on the internal environment in accordance with the vision, mission, and values of PT Bank Sumut Conventional Sub-Branch Office Medan Region, namely culture and.

\section{Discussion}

\section{Cultural Mapping of PT Bank Sumut Conventional Sub-Branch Office for Medan Area at this time.}

Through the results of the mapping in this study, it is known that at PT Bank Sumut Conventional Sub-Branch Office Medan Region, the current clan culture is $23 \%$, the current adhocracy culture is $27 \%$, the current market culture is $24 \%$, then the current hierarchy culture is $26 \%$. Through the mapping chart in this study, it is known that based on the perceptions of all employees, the current corporate culture is more dominant in adhocracy and hierarchy. The culture of PT Bank Sumut Conventional Sub-Branch Office Medan Region is currently dominated by an adhocracy culture where employees can freely explore and channel fresh, creative, and innovative ideas, as well as forwardlooking and independent. The leadership style developed is more of an innovator, entrepreneur, and visionary leadership. The effectiveness criteria are focused on clear outputs, effective work processes and growth principles. Then the culture of PT Bank Sumut Conventional Sub-Branch Office Medan Region is 
currently also dominated by a hierarchy culture, which focuses on organizational characteristics that are formal, structured and carry out internal control, especially with regulations, specialization, functions and centralization of decisions with strong cultural strengths. And acting as the main glue of cohesion are formal regulations and policies.

\section{Cultural Mapping PT Bank Sumut Conventional Sub-Branch Office Medan Area Expected.}

Through the results of the mapping in this study, it is known that at PT Bank Sumut Conventional Sub-Branch Office Medan Region, the expected clan culture is $27 \%$, the expected adhocracy culture is $25 \%$, the market culture is expected to be $26 \%$, and the expected hierarchy culture is $23 \%$. . Through the mapping chart in this study, it is known that based on the perceptions of all employees, the expected corporate culture is more dominant to clan and market. So it takes a joint effort and joint commitment from employees to encourage the achievement of the company's goals, vision and mission. The type of organizational culture that is expected in the future is clan and market. The two types of culture are in accordance with the organizational culture values at PT Bank Sumut. The organizational culture of PT Bank Sumut is summarized in three points, namely service culture, marketing culture and risk culture. These three organizational cultures consist of seven basic cultural values with the acronym BEST, namely Trusted, Energetic, Friendly, Friendly, Safe, High Integrity and Commitment. So it can be concluded that employees expect PT Bank Sumut Conventional Branch Office Medan Region to become a company dominated by clan culture type that focuses on organizational characteristics that are oriented towards teamwork, participation and consensus in the organization. Like a family and therefore places great emphasis on a working environment that is togetherness, kinship, humane, team commitment, and obedience. Every employee has a sense of trust, energetic, friendly, friendly among employees. The leaders or leaders of the company are considered as mentors and even as a father figure who acts as the head of the family. In more detail, this type of clan culture illustrates that the company has a familial type of culture that strives to achieve consensus and commitment through involvement and communication between employees and appreciates cooperation and participation.

The work environment must be open and friendly which allows everyone to interact and share. The future market culture is that employees expect PT Bank Sumut Conventional Sub-Branch Office Medan to be a company built on the basis of dynamics of competition and the achievement of real results, the focus is on goals or results. With this type of culture, PT Bank Sumut 
Conventional Sub-Branch Office Medan Region is centered on the external environment, namely its customers, where PT Bank Sumut has high integrity and is committed. They prioritize the interests of customers or market share and company profits compared to employee satisfaction and human resource development. The shared goal of PT Bank Sumut Conventional Sub-Branch Office Medan Region is to gain the biggest profit, gain the largest market share and beat its competitors. Success in the context of a company characterized by market culture is to gain the largest market share and become a market leader.

\section{CONCLUSION}

Overall, the type of organizational culture currently perceived by employees of PT Bank Sumut Conventional Sub-Branch Office Medan is Adhocracy Culture and the expected type of culture is Clan Culture. This shows that currently employees feel PT Bank Sumut Conventional Sub-Branch Office Medan Region as an organizational culture that emphasizes innovation, creativity, and the discovery of something new and is a dynamic culture or adhocracy culture. However, the adhocracy culture is no longer the culture that most employees expect in the future. The culture that is expected to occur at PT Bank Sumut Conventional Sub-Branch Office Medan is the clan culture. This shows that employees in the future want to form a strong company accompanied by encouragement for employee moral development and strong teamwork. In the clan culture, the organization is expected to be a fun place like in one big family.

\section{REFERENCES}

Cameroon, K. S., \& Quinn, R. E. 2006. Diagnosing and Changing Organizational Culture: Based On The Competing Value Framework. United Stated Of America: Josey Bass.

Cameroon, K. S., \& Quinn, R. E. 2011. Diagnosing and Changing Organizational Culture: Based On The Competing Value Framework. United Stated Of America: Josey Bass.

George, Jennifer \& Jones. 2012. Understanding and Managing Organizational Behaviour. New Jersey: Pearson Education, Inc.

Moeheriono. 2012. Pengukuran Kinerja Berbasis Kompetensi. Jakarta: PT Raja Grafindo Persada.

Rakhman, A. 2018. Analisis Budaya Organisasi Menggunakan Metode Organizational Culture Assessment Instrument (OCAI). Jurnal Ilmu Manajemen Mulawarman, 3(4). 
Saputra, Dhany., dan Djastuti. 2015. "Pengaruh Budaya Organisasi dan Motivasi Terhadap Kinerja Karyawan Hotel Plaza Semarang", Diponegoro Journal Of Management, Volume 4 Nomor 1.

Wibowo. 2010. Budaya Organisasi : Sebuah Kebutuhan untuk Meningkatkan Kinerja Jangka Panjang. Jakarta: PT Rajagrafindo Persada. 